\title{
Tablet PC Language Learning Game in Taiwan Higher Education
}

\author{
Chia-Tsung Lee, Chia-Hui Lin, and Chun Ying Chen
}

\begin{abstract}
The tablet PC (TPC) is increasing in popularity and becoming more common for instructors to utilize (Stickel, 2009). The tablet PC (TPC) device can promote teaching and learning in students through interaction, collaboration, active learning, class engagement, and high-quality feedback (Klara, 2009; Steinweg, 2006). The background-knowledge language game helps students understand and enjoy game-based texts. A non-experimental, quantitative, SPSS 17.0 research design explores the relationship between background demographic characteristics, learning styles, class atmosphere, foreign language class anxiety, technology acceptance, and language proficiency. A sample survey of 250 higher education students was developed with six components.
\end{abstract}

Indexed Terms-Classroom environment, higher education, language learning game, learning styles, tablet PC, technology acceptance.

\section{INTRODUCTION}

The tablet PC (TPC) is becoming increasingly popular and more common for instructors to utilize [1]. Unlike traditional computer technology, mobile technology is limited because it lacks spontaneity and interactivity. The tablet PC (TPC) device can create various possibilities for promoting teaching and learning through student interaction, collaboration, active learning, class engagement, and high quality feedback [2], [3].

The background-knowledge language game helps students understand and enjoy game-based texts and helps teachers motivate reluctant students to learn language from the connection game to language learning [4].

Collaborative global financial institutions, agencies and a free-market economy suggest that competition has become a major player in higher education. Severe competition exists among universities at institutional, local, national, and global levels. Thus, some governments are eager to improve their competitive advantages by investing in specific institution development to build "world class" universities [5]. The number of junior colleges, colleges, and universities has increased in the past decade in Taiwan. In 1998, there were 137 colleges and universities in Taiwan, and 165 in 2010, including 53 colleges and 112 universities and private colleges [6]. The number of private colleges resulting from

Manuscript received October 7, 2011; revised October 26, 2011.

C.-T. Lee is with National Taichung University of Education, Taiwan (e-mail: leect@ntcu.edu.tw).

C.-H. Lin is with Toko University, Taiwan (e-mail: Tinalin26@hotmail.com).

C. Chen is with National Taichung University of Education, Taiwan (e-mail: cychen666@gmail.com). upgrading junior colleges to college has increased rapidly [6].

\section{LiteratURE REVIEW AND HyPOTHESIS DEVELOPMENT}

Computer learning may be beneficial for educators, teacher training, student infrastructure development, curriculum development, assessment reform, and formation evaluation. Language games are methods of linguistic communication [7]. Language learning games reduce stress and increase learner motivation for language training. However, not all games are equivalent. Some learners take advantage of multimedia language learning games, while others prefer authentic linguistic experiences in the classroom or self-study [8].

\section{A. Higher education}

In 2003, the Shanghai Jiao Tong University Institute of Higher Education first issued the first Academic Ranking of World Universities, also known as the Shanghai rankings. The global university ranking system measures four qualities: a) quality of education; b) quality of faculty; c) research output; d) per capital performance [9], [5]. The combined ranking mechanism becomes a by-product of the competition phenomenon of universities. However, the rankings are biased toward the English-speaking world because the indicators used for publications are in the English language. While the quality assurance mechanism has become prevalent worldwide, most countries evaluate national universities, but leave private and cross-border education unregulated [5].

Given the rapid economic development in Taiwan, the Taiwan government expanded the availability of higher education in the late 1980s [10]. However, technological and vocational education institutions have steadily increased in Taiwan in recent years. Schools cannot acquire enough students to enroll, even after a second recruiting procedure [11].

\section{B. Tablet PC language learning}

The theoretical framework of Vygotsky [12] is based on social interaction that focuses on cognition development. This theory identifies three major constructs: social interaction, the more knowledgeable other (MKO), and the zone of proximal development (ZPD). In the past 30 years, the theory has complimented the work of Bandura [13], and revised and adapted to the situated learning theory of Lave [14].

\section{Language learning game}

The definition of the language learning game is, "The 
formal definition lays out the players, their preferences, their information, the strategic actions available to them, and how these influence the outcome" [15]. The game theory focuses on situations resulting from people's action. The game may be played by one player or many people playing together [16]. "Game theory is typically taught in the environment" and the game attracts an interested audience [16]. John and Oskar [17] introduced and developed the game theory based on a branch of applied mathematics. The game theory has been revised and adapted to subgame perfect equilibria by Selten [18], the concept of complete information, and Bayesian games by John [19]. The game theory also applied to biology in 1970 by John Maynard Smith.

\section{Learning styles}

Napaporn [20] studied cognitive learning styles of EFL students. He used a non-experimental, casual comparative, quantitative design of 210 undergraduate students to compare current theories with the learning styles inventory (LSI) developed by Kolb [21].

A probability, systematic sampling plan resulted in a data sample of 210. Language learning styles were used to measure strategy-orientation, meaning-orientation, process-orientation, and failure-resilience. The average mean of language learning styles was 3.40 and the standard deviation was 0.34 . Findings supported the hypothesis of students' language learning styles classified by gender and English background knowledge, but did not support the hypothesis of language learning styles in terms of fields of study. Napaporn's interpretation of these findings led to the following conclusions of the importance of determining students' cognitive learning styles and implications for teachers to encourage students to learn from failures and to demonstrate the effectiveness of learning strategies. Future study should consider student differences, and lectures should provide students more opportunities to use various learning styles.

\section{E. Foreign language classroom anxiety}

Foreign language anxiety is defined as "a distinct complex of self-perceptions, beliefs, feelings, and behaviors related to classroom language learning arising from the uniqueness of the language learning process" [22].The literature describes three types of anxiety: trait anxiety (a personality trait), state anxiety (apprehension experienced at a particular moment in time), and situational anxiety (anxiety experienced in a well-defined situation) [23], [24], [25].

\section{F. Technology acceptance}

Technology acceptance is "an individual's psychological state with regard to his or her voluntary or intended use of a particular technology" [26]. The technology acceptance model (TAM), originally created by Davis [27], is based on the theory of reasoned action [28] in psychology research. The TAM derives from a theory that describes how users come to use and accept a technology [27]. The TAM consists of "perceived usefulness" and "perceived ease" to measure user acceptance [27]. The TAM proposes that perceived usefulness and perceived ease of use of technology are predictors of user's attitude towards the technology, subsequent behavioral intentions, and actual usage [27], depicted in Fig. 1.

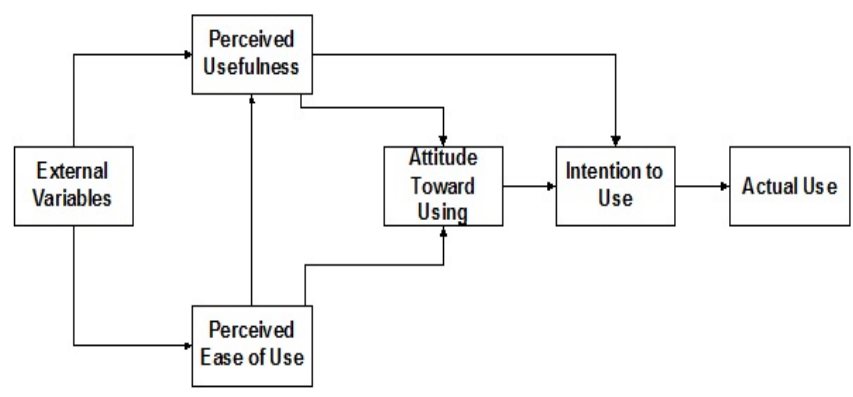

Fig. 1. Technology Acceptance Model [5].

\section{G. Language proficiency}

Clark [29] described language proficiency as learner ability. Brière [30] stated: "The term 'proficiency' may be defined as: the degree of competence or the capability in a given language demonstrated by an individual at a given point in time independent of a specific textbook, chapter in the hook, or pedagogical method".

The three instruments included (1) The foreign language classroom anxiety scale (FLCAS) [22], used to measure communication apprehension, test anxiety, and fear of negative evaluation with a 33-item survey. (2) The English proficiency test, designed as a pre-test and post-test. (3) A semi-structured interview containing two questions about reading and writing skills.

The results showed a significant decrease in the top five sources of language classroom anxiety and overall language anxiety. The post-test of language proficiency scores were also higher than the pre-test. The research recommended that teachers pay more attention to the learning anxiety of students and create a low anxiety, supportive, and friendly learning environment.

\section{H. Research Questions}

1. Are there differences in student background demographic characteristics, learning styles, class atmosphere, foreign language class anxiety, technology acceptance, and language proficiency with and without preference for tablet PC language learning for Taiwanese college students?

\section{Hypothesis}

H1: Background demographic characteristics with gender have significant explanatory variables of perceived language proficiency (spoken tasks, comprehension, interaction strategies, and writing tasks).

H2: Background demographic characteristics with gender have significant explanatory variables of perceived learning styles (visual, auditory, and kinesthetic), class atmosphere, foreign language class anxiety, and technology acceptance.

H3: Family Condition (double income family, single parent family, grandparenting, and learning styles (visual, auditory, and kinesthetic) is statistically significant for language proficiency (spoken tasks, comprehension, interaction strategies, and writing tasks).

H3a: Family Condition (double income family, single parent family, grandparenting, and learning styles (visual, auditory, and kinesthetic) is statistically significant for language proficiency with spoken tasks.

$\mathrm{H} 3 \mathrm{~b}$ : Family Condition (double income family, single parent family, grandparenting, and learning styles (visual, 
auditory, and kinesthetic) is statistically significant for language proficiency with comprehension.

$\mathrm{H} 3 \mathrm{c}$ : Family Condition (double income family, single parent family, grandparenting, and learning styles (visual, auditory, and kinesthetic) is statistically significant for language proficiency with interaction strategies.

H3d: Family Condition (double income family, single parent family, grandparenting, and learning styles (visual, auditory, and kinesthetic) is statistically significant for language proficiency with writing tasks.

H4: Preference for tablet PC language learning has a greater explanation of the relationship of student background demographic characteristics, learning styles, class atmosphere, foreign language class anxiety, technology acceptance, and language proficiency than without a preference for tablet PC language learning for Taiwanese college students.

H5: The language learning game has a greater explanation of the relationship of student background demographic characteristics, learning styles, class atmosphere, foreign language class anxiety, technology acceptance, and language proficiency than without the language learning game for Taiwanese college students.

\section{Methodology}

\section{A. Research design}

This study used a non-experimental, quantitative, SPSS 17.0 research design to explore the relationship of background demographic characteristics, learning styles, class atmosphere, foreign language class anxiety, technology acceptance, and language proficiency.

\section{B. Population and sampling plan \\ C. Target population}

The Taiwan Ministry of Education Department of Statistics [20] indicated nine college and universities in Taichung City and County and three colleges and universities in Chiayi City and County. Target populations were 177 college students in Taiwan. The convenience sample included students enrolled in National Taichung University of Education, Ling Tung University, and Toko University in Taiwan.

\section{Sampling plan}

The entire accessible population was invited to participate in the study. However, the final data sample was self-selected depending on those who agreed to participate in the study.

\section{E. Instrumentation}

The instrument utilized in this study is composed of six parts: The surveys employed (1) Background Demographic Characteristics, developed by the researchers, (2) The Index of Learning Styles (ILS), developed by Felder and Silverman [31], (3) Class atmosphere, measured from the On-Line Class Satisfaction Survey Questionnaire developed by Cheng, Liu, Ko \& Lin [32], (4) The Foreign language classroom anxiety, measured from the Foreign Language Classroom Anxiety Scale (FLCAS) developed by Horwitz, Horwitz, and Cope [22], (5) The Technology Acceptance Model(TAM), developed by Davis, [27], and (6) Language Proficiency, measured from North \& Schneider [33].

\section{RESUlts}

\section{A. Independent Sample t-tests}

Levene's test for Equality of Variances reports on research question 1 in which the variances of students who learned with and without preferring tablet PC language learning for the language learning game $(p=0.00)$, language proficiency with comprehension $(p=0.038)$, interaction strategies ( $p=0.045)$, and writing tasks $(p=0.05)$ differed significantly with and without preferring tablet PC language learning.

\section{B. Logistic regression analysis}

In Hypothesis 1, gender is statistically significant with language proficiency with spoken tasks.

TABLE I: LOGISTIC REGRESSION ANALYSIS WITH GENDER AND LANGUAGE PROFICIENCY WITH SPOKEN TASKS, COMPREHENSION, INTERACTION STRATEGIES, AND WRITING TASKS

\begin{tabular}{llll}
\hline & B & S.E. & Sig. \\
\hline Spoken Tasks & .491 & .244 & .044 \\
Comprehension & .238 & .262 & .364 \\
Interaction Strategies & -.321 & .254 & .206 \\
Writing Tasks & -.410 & .216 & .058 \\
\hline
\end{tabular}

In Hypothesis 2, gender is not statistically significant with learning styles, class atmosphere, foreign language class anxiety, and technology acceptance.

TABLE II: LOGISTIC REGRESSION ANALYSIS WITH GENDER AND LEARNING STYles, Class Atmosphere, Foreign LANGUage Class ANXIETy, AND TECHNOLOGY ACCEPTANCE

\begin{tabular}{llll}
\hline & B & S.E. & Sig. \\
\hline Learning Styles & -.503 & .276 & .068 \\
Class Atmosphere & .293 & .164 & .073 \\
$\begin{array}{l}\text { Foreign Language Class } \\
\text { Anxiety }\end{array}$ & .082 & .230 & .721 \\
$\begin{array}{l}\text { Technology Acceptance } \\
\text { P }\end{array}$ & -.029 & .156 & .850 \\
\hline
\end{tabular}

\section{Two-way ANOVA analysis}

In Hypothesis 3a, 3b, 3c, 3d there was no significant main effect for family condition, learning styles, and language proficiency.

\section{Multiple Regression R Square Analyses}

Both programs were statistically significant, but an absence of tablet PC language learning had higher explanatory power $(10.2 \%)$ than with tablet PC language learning $(9.8 \%)$. In conclusion, research Hypothesis 4 was not supported.

Both programs were statistically significant; however, the language learning game had higher explanatory power $(42.6 \%)$ than without the language learning game (32.4\%). In conclusion, research Hypothesis 5 was supported. 
TABLE III: MULTIPLE REGRESSION R SQUARE ANALYSES OF BACKGROUND DEMOGRAPHIC CHARACTERISTICS, LEARNING STYLES, ClASS ATMOSPHERE, Foreign LANGUAGE Class ANXIETy, TECHNOLOGY ACCEPTANCE, AND LANGUAGE PROFICIENCY WITH AND WiTHOUT PREFERRING TABLET PC LANGUAGE LEARNING

\begin{tabular}{cccccc}
\hline & Model & $R$ & $R$ & $\begin{array}{c}\text { Adjusted } \\
\text { Square }\end{array}$ & $\begin{array}{c}\text { Std. Error } \\
\text { of the } \\
\text { Estimate }\end{array}$ \\
& & & & & \\
\hline $\begin{array}{c}\text { Tablet PC } \\
\text { Language } \\
\text { Learning } \\
\text { Without }\end{array}$ & 1 & .313 & .098 & .044 & .510 \\
$\begin{array}{c}\text { Tablet PC } \\
\text { Language } \\
\text { Learning }\end{array}$ & 2 & (a) & & & \\
\hline
\end{tabular}

TABLE IV: MULTIPLE REgRESSION R SQUARE ANALYSES OF BACKGROUND DEMOGRAPHIC CHARACTERISTICS, LEARNING STYLES, Class AtmosPhere, Foreign LANGUAGE Class ANXIETy, TECHNOLOGY ACCEPTANCE, AND LANGUAGE PROFICIENCY WITH AND WITHOUT LANGUAGE LEARNING GAME

\begin{tabular}{cccccc}
\hline & Model & $R$ & $\begin{array}{c}R \\
\text { Square }\end{array}$ & $\begin{array}{c}\text { Adjusted } \\
R \text { Square }\end{array}$ & $\begin{array}{c}\text { Std. Error } \\
\text { of the } \\
\text { Estimate }\end{array}$ \\
\hline $\begin{array}{c}\text { Language } \\
\text { Learning } \\
\text { Game }\end{array}$ & 1 & $.653(\mathrm{a})$ & .426 & .401 & .838 \\
$\begin{array}{c}\text { Without } \\
\text { Language } \\
\text { Learning } \\
\text { Game }\end{array}$ & 2 & $.569(\mathrm{a})$ & .324 & .263 & .911 \\
\hline
\end{tabular}

\section{E. Reliability analysis}

This study estimated the reliability of learning styles, class atmosphere, foreign language class anxiety, technology acceptance and language proficiency with spoken tasks, comprehension, interaction strategies, writing tasks. Cronbach's alphas and item analyses were conducted on all variables: alphas $=.768$.

TABLE V: CRONBaCh Alpha COEFFicients of LEARning Styles, Class ATMOSPHERE, Foreign LANGUAGE Class ANXIETY, TECHNOLOGY ACCEPTANCE AND LANGUAGE PROFICIENCY WITH SPOKEN TASKS, COMPREHENSION, INTERACTION STRATEGIES, WRITING TASKS

$$
\begin{array}{cl}
\text { Cronbach's } & \begin{array}{l}
\text { Cronbach's Alpha } \\
\text { Based on } \\
\text { Alpha }
\end{array} \\
\text { Standardized Items } \\
.768
\end{array}
$$

$\mathrm{N}$ of Items

\section{CONCLUSION}

This study explored the relationship among demographic characteristics (gender, family condition, father and mother education, school year, language learning game, and preference for using tablet PC during the English course), learning styles (visual, auditory, and kinesthetic), class atmosphere, foreign language class anxiety, technology acceptance, and language proficiency (spoken tasks, comprehension, interaction strategies, and writing tasks) among 250 random selected Taiwan higher education college students. The survey instruments were used in three colleges for data collection. Two hundred and fifteen survey questionnaires were returned, with a return rate of $84 \%$.

Analysis of the research results found a significant relationship between language learning for the language learning game, language proficiency with comprehension, interaction strategies, and writing tasks with and without preferring tablet PC language learning. Gender was also statistically significant in language proficiency with spoken tasks. The language learning game had a greater explanation for the relationship of all variables than without the language learning game for Taiwanese college students. A non-preference for the tablet PC language learning had a greater explanation of the relationship of all variables than a preference for the tablet PC language learning for Taiwanese college students.

However, gender showed no statistical significance with learning styles, class atmosphere, foreign language class anxiety, and technology acceptance, and no statistical significance demonstrated for family condition and learning styles for language proficiency.

\section{PRACTICAL IMPLICATIONS}

The Taiwan Minister of Education has attempted to improve Taiwanese English ability. Digital language learning has become a very popular method in Taiwan to compete with overseas countries worldwide. The findings of the current study have important implications for educational organizations, the Taiwan government, companies, and other researchers.

\section{FUTURE STUDY AND LIMITATIONS}

The sampling method of this study was limited to the accessible population, and the research design was limited to the non-experimental. This may threaten internal validity. The colleges in this study were limited to three colleges in Taiwan, with only 250 college students in the accessible population. All of the participants were Taiwanese. The research findings may not be generalized to other countries.

Future studies might adopt a qualitative research design by interviewing participants and eliciting participant opinions about tablet PC language learning for Taiwanese college students. Future studies should also enlarge the accessible population to strengthen generalizability of this study and include other cultures or counties to explore the difference among all variables for tablet PC language learning. Applying and replicating the findings of this study to different language learners in Taiwan would also be worthy of further research.

\section{ACKNOWLEDGMENT}

Thanks to all of my family who support me and my co-authors who instruct me to do the research together. I do really benefit a lot from them to contribute myself to the whole educational areas. 


\section{REFERENCES}

[1] M. Stickel, "Impact of lecturing with the tablet PC on students of different learning styles," 39th ASEE/IEEE Frontiers in Education Conference. San Antonio, TX, 2009.

[2] G. C. Klara, "The mobile gymanisum Using Tablet PCs in physical education”. Journal of Physical Education, 80(2), 24-31, 2009.

[3] S. B. Steinweg, "Teaching through the screen: Using a tablet PC to provide feedback in online classes," Rural Special Education Quarterly, 25(2), 8-12, 2002

[4] K. Jolley, "Video game to reading: reaching out to reluctant readers," English Journal, 97(4), 81-86, 2008.

[5] L. M. Portnol, S. S. Bagley, and V. D. Rust, "Mapping the Terrain: The Global Competition Phenomenon in Higher Education," In Portnoi, V. D., Rust, V. D. \& Bagley, S. S. (Ed.) Higher education, policy, and the global competition phenomenon. New York, NY: Palgrave Macmillan, 2010

[6] Ministry of Education of Republic of China. (2011). Education in Taiwan.. Retrieved March 20, 2011. Available: http://english.education.edu.tw/public/Attachment/011114493771.pdf

[7] H. R. Fischer, "Language games and histories: Wittgenstein, Bateson, and Schapp on the rold of the language in therapy," Kybernetes, 36(7/8), 1037-1046, 2007

[8] E. Dalton, Language learning game: why, when and how. Retrieved May 11, 2011. Available: http://gaeacoop.org/dalton/publications/LanguageGames.pdf

[9] S. Marginson, "Global Comparisons and the University Knowledge Economy,'In Portnoi, V.D., Rust, V. D. \& Bagley, S. S. (Ed.) Higher education, policy, and the global competition phenomenon. New York NY: Palgrave Macmillan, 2010

[10] H. A. C. Lin and C. H. Yang, "An analysis of educational inequality in Taiwan after the higher education expansion," Social Indicators Research, 90(2), 295-305. Retrieved April 15, 2011, from ProQuest database, 2009.

[11] H. E. Mo, and Y. F. Chen, "An empirical study on the renaming department for higher technological and vocational education in Taiwan," Journal of American Academic Business, 16(2), 270-278, 2011.

[12] L. S. Vygotsky, Mind in Society. Cambridge, MA: Harvard University Press, 1978.

[13] A. Bandura, Social Learning Theory. New York: General Learning Press, 1977.

[14] J. Lave, Cognition in Practice: Mind, mathematics, and culture in everyday life. Cambridge, UK: Cambridge University Press, 1988.

[15] T. L. Turocy and B. Stengel, Game theory. Encyclopedia of Information Systems, Academic Press, 2001.

[16] S. Wallance, "Game theory and interactive learning computers in the classroom," Unpublished master's thesis, University of Oregon, United states, 2006.

[17] V. N. John and M. Oskar, "Theory of games and economic behavior," Princeton University Press, 1944.

[18] R. Selten, "Spieltheoretische Behandlung eines Oligopolmodells mit Nachfragetragheit, "Zeitschrift für die gesamte Staatrwissenschaft, $121,301-24,667-89,1965$.

[19] C. H. John, "Games with incomplete information played by Bayesian players," Management Science 14, 159-182, 320-334, 486-502. 1967.

[20] S. Napaporn, Congitive learning styles of EFL students, Journal of College Teaching and Learning, 8(2), 15-23. Retrieved June 21, 2011 from ProQuest database, 2011.

[21] D. A. Kolb, Experiential Learning, Englewood Cliffs, NJ.: Prentice Hall, 1984.
[22] E. K. Horwitz, M. B. Horwitz, and J. Cope, "Foreign language classroom anxiety," The Modern Language Journal, 70(2), 123-132, 1986.

[23] R.-U. A. Nisa, A. Musarrat, M. A. Nadeem, and N. Anjum, "An investigation of for foreign language classroom anxiety and its relationship with students' achievement," Journal of College Teaching and Learning, 7(11), 33-40. Retrieved January 21, 2011, from ProQuest database, 2010.

[24] M. W. Eysenck, "Anxiety, learning, and memory: A reconceptualization," Journal of Research in Personality, 13, 363-385, 1979.

[25] P. D. Maclntyre, and R. C. Gardner, "Anxiety and second language learning: Towards a meoretical clarification,” In: E. K. Horwitz \& D. J. Young (Eds.), Language anxiety: From theory and research to classroom implications (pp. 41-54). Englewood Cliffs, New Jersey: Prentice Hall, 1991.

[26] U. E. Gattiter, "Technology management in organizations," Newbury Park, CA Sage, 1990.

[27] F. D. Davis, "Perceived usefulness, perceived ease of use, and user acceptance of information technology," MIS Quarterly, 13(3), 319 340. Retrieved May 9, 2011, from ProQuest database, 1989.

[28] M. Fishbein and I. Ajzen, Belief, attitude, intention and behavior: an introduction to theory and research. Reading, MA: Addison-Wesley, 1975

[29] J. L. D. Clark, "Foreign language testing: Theory and practice. Philadelphia," PA: The Center for Curriculum Development, 1972.

[30] E. J. Briere, Are we really measuring proficiency with our foreign language tests? In H.B. Allen \& R.N. Campbell (eds.), Teaching English as a second, 1972.

[31] R. M. Felder and L. K. Silverman, "Learning and Teaching Styles in Engineering Education," Engineering Education, Vol. 78, No. 7, pp. 674-681, 1988.

[32] S. S. Cheng, E. Z. Feng, H. W. Ko, and C. H. Lin, "Learning with online tutoring: rural area students' perception of satisfaction with synchronous learning," International Journal of Computers and Communications, 2(1), 2007.

[33] B. North and G. Schneider, "Scaling description for language proficiency scales," Language Testing, 15(2), 217-163, 1998.

Chia-Tsung Lee is an assistant professor who works for the National Taichung University of Education. His research interests include comparative education and higher education. E-mail:leect@ntcu.edu.tw

Chia-Hui Lin was born in Taiwan and studied the Ph.D for the Global Leadership, with a specialization in Educational Leadership in Lynn University, Florida, United States. Her research interests include computer-assisted language learning (CALL), higher education, and language learning. The current job that she works for the Toko University and to be the assistant professor in Taiwan. E-mail:Tinalin26@hotmail.com

Chun Ying Chen is an associate professor and director in the Center for General Education for National Taichung University of Education, Taiwan E-mail: cychen666@gmail.com. 